\title{
Watermills and windmills as monuments in Poland - protection of cultural heritage in situ and in open-air museums
}

\author{
Zachariasz Mosakowski\# - Dariusz Brykała\#* - Maciej Prarat - Daria Jagiełło \\ - Zbigniew Podgórski - Piotr Lamparski
}

Mgr. Zachariasz Mosakowski

Polish Academy of Sciences

Institute of Geography and Spatial Organization

Department of Environmental Resources and Geohazards

ul. Kopernika 19

87-100 Toruń

Poland

e-mail: zachary@twarda.pan.pl

Dr Dariusz Brykała, PhD

Polish Academy of Sciences

Institute of Geography and Spatial Organization

Department of Environmental Resources and Geohazards

ul. Kopernika 19

87-100 Toruń

Poland

e-mail:darek@geopan.torun.pl

Dr Maciej Prarat, PhD

Nicolaus Copernicus University

Faculty of Fine Arts

Department for the Study and Protection of Cultural Heritage

ul. Sienkiewicza 30/32

87-100 Toruń

Poland

e-mail: mprarat@umk.pl

Mgr. Daria Jagiełło

Nicolaus Copernicus University

Faculty of Fine Arts

Department for the Study and Protection of Cultural Heritage

ul. Sienkiewicza 30/32

87-100 Toruń

Poland

e-mail:dar.jag@doktorant.umk.pl

\# these authors contributed equally to this work

*corresponding author
Dr hab. Zbigniew Podgórski, Assoc. Prof.

Kazimierz Wielki University

Institute of Geography

Department of Landscape Geography

Pl. Kościeleckich 8

85-033 Bydgoszcz

Poland

e-mail: zbigniew.podgorski@ukw.edu.pl

Dr Piotr Lamparski, PhD

Polish Academy of Sciences

Institute of Geography and Spatial Organization

Department of Environmental Resources and

Geohazards

ul. Kopernika 19

87-100 Toruń

Poland

e-mail: piotr@geopan.torun.pl

Watermills and windmills as monuments in Poland-protection of cultural heritage in situ and in open-air museums

This paper presents the results of research on the history of the protection of mills as objects of cultural heritage on Polish lands. First, the spatial distribution of over 20,000 mills at the beginning of the previous century is characterized, then the main actions undertaken for their protection in the nineteenth and twentieth centuries are discussed. Merely 3.4\% of mills that worked in the past are now protected as monuments and recorded in the national register. Most of them remain in their original locations (in situ), and another 71 windmills and 22 watermills have been relocated to open-air museums. These specific institutions face a particularly important task involving the necessity to retain the original functionality of the mills.

Keywords: mills, monuments, cultural heritage, open-air museums, Poland 


\section{Introduction}

Human use of the energy of wind and flowing water became a stimulus for the dynamic growth of civilization. ${ }^{1}$ It is difficult to pinpoint unambiguously when humans began to benefit from wind energy. In the fourth century BCE, the first known description of the application of a windmill for water pumping was created in India, and in the second century BCE China was already using winch-shaped windmills to irrigate cultivable fields. At the beginning of the Common Era, windmills were used in the countries of the Middle East. The first European windmills operated in the ninth century in England, in the eleventh century in France, and starting from the thirteenth century they became common in other countries of Western Europe. The highest increase in the number of windmills took place in the mid-nineteenth century. During that time, about 200,000 facilities of this type were operating in Europe. ${ }^{2}$ On the other hand, watermills had been used to mill grain in the countries of the Mediterranean Sea Basin since the third century BCE. ${ }^{3}$ Large milling complexes in which water moved about a dozen water wheels already existed in Europe during the first centuries of the Common Era. They provided food for tens of thousands of people in surrounding settlements. ${ }^{4}$ At the beginning of the twelfth century, in France alone there were about 20,000 operational watermills, and by the end of the fifteenth century their number had reached $70,000.5$ Such a high number of milling facilities made them important elements of the cultural landscape. ${ }^{6}$ Watermills and windmills were used not only for milling grain into flour, but also as irrigating devices, sawmills, oil mills, paper mills, gunpowder mills, fulling mills, ironworks and many others. ${ }^{7}$ For whole centuries, their abundant presence in a particular area was an indicator of a high level of economic development.

The earliest indications of the consideration of monuments as significant factors of social and political processes took place already during ancient times. ${ }^{8}$ In the case of products of folk culture, the oldest known records of interest in this regard date back to the sixteenth century in Spain, where the national statistical summary included local legends, customs and the design of folk costumes. Another good example of a country that was early to initiate such actions is Sweden, where legal provisions for cataloguing and protecting remains from the past (such as runestones) functioned from the seventeenth century. ${ }^{9}$

The main research objective of this paper is to present the history of the protection of

\footnotetext{
${ }^{1}$ BLOCH, Marc. Avènement et Conquêtes du Moulin a Eau. In: Annales d'histoire économique et sociale, 7/36, 1935, p. 538-563; REYNOLDS, Terry S. Stronger than a Hundred Men: A History of the Vertical Water Wheel. Johns Hopkins Studies in the History of Technology, Book 7, Baltimore-London: Johns Hopkins University Press, 2002.

${ }^{2}$ HEYMANN, Mathias. Die Geschichte der Windenergienutzung: 1890-1990. Frankfurt/Main-New York: Campus Verlag, 1995.

${ }^{3}$ WIKANDER, Örjan. Archaeological Evidence for Early Water-Mills - an Interim Report. In: SMITH, Norman. (Ed.). History of Technology, 10, 1985, p. 151-180.

${ }^{4}$ LEVEAU, Philippe. The Barbegal water mill in its environment: archaeology and the economic and social history of antiquity. In: Journal of Roman Archaeology, 9, 1996, p. 137-153.

${ }^{5}$ BRAUDEL, Fernand. L'identité de la France, Vol. 3, Paris: Arthaud-Flammarion, 1986.

${ }^{6}$ OLIVER, Stuart. Liquid materialities in the landscape of the Thames mills and weirs from the eighth century to the nineteenth century. In: Area, 45 (2), 2013, p. 223-229; BRYKALA, Dariusz, PODGÓRSKI, Zbigniew. Evolution of landscapes influenced by watermills, based on examples from Northern Poland. In: Landscape and Urban Planning, 198, 2020, article no. 103798.

${ }^{7}$ LUCAS, Adam. Industrial Milling in the Ancient and Medieval Worlds. A Survey of the Evidence for an Industrial Revolution in Medieval Europe. In: Technology and Culture, 46 (1), 2005, p. 1-30.

${ }^{8}$ ARSZYŃSKI, Marian. Idea, pamię́, troska. Rola zabytkón w przestrzeni spotecznej i formy dziatań na rzecz ich zachowania od starożytności do połowy XX w. Malbork: Wydawnictwo Muzeum Zamkowego w Malborku, 2007, p. 11.

${ }^{9}$ ARSZYŃSKI, Idea, pamię́, troska..., p. 50, 67.
} 
traditional watermills and windmills as objects of cultural heritage, ${ }^{10}$ in the context of the development of various approaches to monument conservation on Polish lands. Considering the nature of this research paper, the issues of mill conservation will be presented in a synthetic way - to characterize the whole compilation of objects. The main source that is used to illustrate this process is the analysis of changes in total number of mills over the years, performed in a quantitative and spatial manner, including protected objects in open-air museums (ex situ) and in their original locations (in situ). The prerequisites of this text do not allow for a deeper analysis of problems connected with building construction, or detailed study on the technical solutions used.

The typology of objects includes those propelled with water and wind energy, destined for multiple purposes - mainly for producing flour, but also used as fulling devices, hammer mills, paper mills, sawmills, etc. As technology progressed, water turbines, steam and electric engines began to be used. However, the starting point for the analysis presented here is those mills propelled by the power of nature, with a possibility of their future technical improvement, located both in the countryside and in cities. Among those objects are buildings made of wood, bricks or stone.

The territorial range of research includes an area delimited by the current borders of Poland. By referring to historical activities, it was extended by areas which constituted parts of Poland until the Second World War. The chronological spectrum of research covers a period from the nineteenth century until the present day. The earliest point of this timeframe is related to the dynamic development of milling in the history of Europe, and the end point to the common departure from traditional forms of propulsion for production plants (wind energy and water) in favour of engines and electric motors. Moreover, the end of the nineteenth century also overlaps with the oldest records of conservation care involving mills.

The research was primarily based on the query, study and analysis of comprehensive source literature and archival sources, mainly concerning the inventory of milling facilities in the nineteenth and twentieth centuries. Evaluations of the current preservation of selected objects were performed through on-site research, which enabled the comparison of direct observation with documentation of conservation stored in museums and monument protection offices.

The present paper is constructed of complementary parts corresponding to the adopted research objectives. The first part presents the development of mills at the turn of the nineteenth and twentieth centuries, followed by the discussion (after establishing the resources) of conservation actions undertaken for the protection of this group of monuments, mainly in the twentieth century. Subsequently, the current condition of historical mills driven by water and wind energy is presented in order to reveal actions taken by museums and national monument protection services.

\section{Characteristics of the development of milling on Polish lands}

The first documented information about a watermill on Polish lands involves a facility in Zgorzelec, listed in a document dated $1071 .^{11}$ The first permit for the construction of a wind-

\footnotetext{
${ }^{10}$ Compare with: GLASER-OPITZ, Zoltán, KULLA, Marián, SPIŠIAK, Peter. Vodné mlyny na Slovensku ako fenomén kultúrneho dedičstva. In: Geografické Informácie, 16 (1), 2012, p. 67-76; FAJER, Maria. Watermills - a Forgotten River Valley Heritage - selected examples from the Silesian voivodeship, Poland. In: Environmental \& Socio-economic Studies, 2 (2), 2014, p. 1-9; ÇORAPÇIOĞLU, Gülferah. Conservation of the traditional water mills in the Mediterranean Region of Turkey. In: Journal of Cultural Heritage Management and Sustainable Development, 6 (3), 2016, p. $287-315$. ${ }^{11}$ DEMBIŃSKA, Maria. Przetwórstwo zbożowe w Polsce średniowiecznej (X-XIV wiek). Wrocław: Ossolineum, 1973 , p. 64.
} 


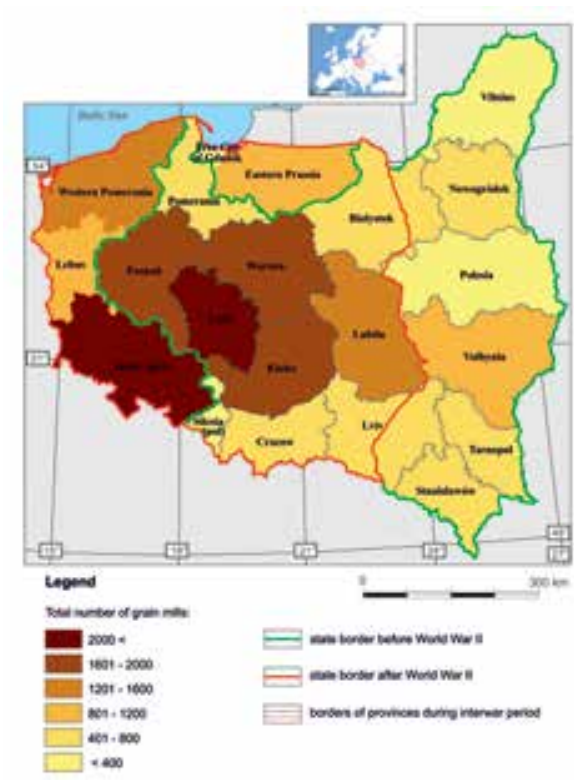

Figure 1: The distribution of grain mills on Polish lands in the early twentieth century (Source: own compilation based on the data presented by: W. Szulc and A. Dzik )

mill was in turn issued in 1271 by Prince Wiesław of Rugia for a monastery in Bialy Buk. A donation act of Pomeranian dukes in favour of Cistercian nuns in Szczecin dated 1289 clearly testifies to an already existing windmill. ${ }^{12}$ From the thirteenth century, there are 344 records of 485 watermills distributed in all regions of the former Poland..$^{13}$ The greatest development of milling in the current area of Poland took place in the sixteenth century. Already in the middle of this century there were approx. 12,000 functioning watermills and windmills. ${ }^{14}$

At the beginning of the twentieth century, in the area of Poland reborn after the First World War, over 15,000 milling plants were inventoried. In addition, further 6,200 mills operated in areas which did not become parts of Poland until after the Second World War (fig. 1). Mills driven by water and wind constituted $90 \%$ of all facilities. The remaining (but considerably larger) ones were provided with internal combustion and steam engines. The majority of such facilities were located in German Silesia and in East Prussia, as well as in the following voivodeships: Warsaw, Poznań and Łódź. It should be mentioned as an interesting fact that at the beginning of the twentieth century, there were still isolated cases of operating horsemills and boat mills on major navigable rivers (on the Vistula, Pripyat, Pisa, Dunajec and Dniester).

On the other hand, the distribution of watermills and windmills, which are represented in almost equal proportions, features a certain noticeable spatial regionalisation. Windmills constituted the most numerous group (over 1,000 such facilities per voivodeship) in Łódź, Poznań and Warsaw. In turn, watermills were the most numerous in German Silesia and in the voivodeships of Kielce, Stanisławów and Cracow.

After the Second World War, in the new reality of a socialist country where all private property was limited to a minimum, there was no place for small milling facilities. Nonetheless, in 1954 in Poland there were still 3,280 inventoried windmills and 6,330 functional facilities using the energy of flowing water. ${ }^{15}$

After examining the collected set of objects, we can generally say, that the dominant type of watermill was the one equipped with a vertical water wheel, both of overshot and undershot subtypes. The choice of water wheel subtype was then determined by local physiographic con-

\footnotetext{
${ }^{12}$ DEMBIŃSKA, Przetwórstwo zbożowe w Polsce średniowieçnej..., p. 128-129.

${ }^{13}$ DEMBINSKA, Przetwórstwo źbożowe w Polsce średniowiecznej..., p. 78.

${ }^{14}$ BARANOWSKI, Bohdan. Polskie mlynarstwo. Wrocław: Ossolineum, 1977, p. 29.

${ }^{15}$ PAWLIK, Mieczysław. Wiatraki pótnocno-wsschodniej Polski. Rozprawy Uniwersytetu Warszawskiego, 273, Białystok: Uniwersytet Warszawski, 1984; SPOZ, Jerzy, JAŚKIEWICZ, Jacek, LEWANDOWSKI, Stanisław, SAKOWICZ, Mieczysław, TIERESZKO, Urszula. Sto lat energetyki wodnej na ziemiach polskich. Warszawa: Towarzystwo Elektrowni Wodnych, 1998.
} 
ditions, ${ }^{16}$ mainly the shape of the river valley, the slope of the watercourse, and water resources. From a second half of the nineteenth century water turbines became increasingly popular. After analysing how the energy was transmitted, transformed and used to propel devices, we can say that until the second half of nineteenth century the most popular form was the traditionally constructed turbine in which energy from the main horizontally installed shaft was transmitted to a vertical shaft equipped with additional gears. This can be clearly seen when we consider the cubature of mill buildings: the most common type were one-storey buildings, sometimes with a usable attic. Multi-storey brick industrial plants started to become popular at the end of the nineteenth century.

With regards to windmills, there was a wide variety of types in Poland, starting from the oldest and most numerous, the post mill, in which the whole construction rotated around the main pole. Mills where only the dome that holds the shaft is movable are called smock mills (if made of wood on the plan of a polygon) or tower mills (if made of bricks on the plan of a circle). The last, less popular type, called a paltrock mill, was made from wood and quite similar to a post mill, but rotatable thanks to a kind of a roller bearing installed in its base.

\section{The historical background of the protection of mills on Polish lands Up to the end of the Second World War}

The beginnings of the idea of conservation in Poland can be sought in the seventeenth and eighteenth centuries; ${ }^{17}$ however, it was not until the establishment of institutional services when practical actions in this regard were made possible. The first country worth mentioning among those who annexed Polish land after the partitions made near the end of the eighteenth century is Prussia, in which the office of a conservator of monuments was established as early as in $1843,{ }^{18}$ while until the end of the 1890 s it was the location of provincial monument protection offices. ${ }^{19}$ Afterwards, in 1853, Austria established a Central Commission for the Research and Preservation of Architectural Monuments. ${ }^{20}$ It was not until 1906 that the Society for Protection of Monuments of the Past was established in the Russian partition, being a social body substituting, in this regard, for missing institutions. ${ }^{21}$ The situation changed along with the creation of the Polish state. A decree from the Regency Council about care for monuments of art and culture was issued on 31 October $1918 .^{22}$ It included the definition of a monument, which covered not just works of architecture, but also urban layouts and historic greenery. The surroundings of a monument were also to be protected. A short time later, the issue of the establishment of district monument protection offices was standardised. ${ }^{23}$ The

\footnotetext{
${ }^{16}$ Compare with: BRYKA£A, Dariusz. Uwarunkowania przyrodnicze lokalizacji młynów wodnych w zlewni Skrwy. In: GERMAN, Krystyna, BALON, Jarosław (eds). Przemiany środowiska prayrodniczego Polski a jego funkcjonowanie. Kraków: Instytut Geografii i Gospodarki Przestrzennej UJ, 2001, p. 164-171.

${ }^{17}$ FRYCZ, Jerzy. Restauracja i konserwacja zabytków architektury w Polsce w latach 1795-1918. Warszawa: Państwowe Wydawnictwo Naukowe, 1975, p. 17.

${ }^{18}$ JOKILEHTO, Jukka. A History of Architectural Conservation. New York: Routledge, 1999, p. 255.

${ }^{19}$ LEZIUS, Hermann. Das Recht der Denkmalpflege in Preussen. Berlin, 1908, p. 27.

${ }^{20}$ ARSZYŃSKI, Idea, pamię́, troskea..., p. 97.

${ }^{21}$ FRYCZ, Restauracja i konserwacja zabytków..., p. 190.

${ }^{22}$ Decree of the Regency Council about care for monuments of art and culture (Journal of Laws 1918, No. 16 item 36).

${ }^{23}$ DETTLOFF, Paweł. Odbudowa i restauracja zabytków architektury w Polsce w latach 1918-1939. Teoria i praktyka. Kraków: Towarzystwo Autorów i Wydawców Prac Naukowych UNIVERSITAS, 2006, p. 46.
} 
office of the General Conservator of Monuments was established in $1930 .^{24}$

The nineteenth century was also a time of increased interest in the rapidly vanishing folk culture. What is important is that it was recognised as a carrier of national identity. ${ }^{25}$ This was one of the reasons behind the development of museums and collections. The exhibitions in Cracow in 1887 and Lviv in 1894 were the first to present examples of original folk architecture from southern and eastern Poland. ${ }^{26}$

The open-air museum in Stockholm established by Artur Hazelius in 1891 was the world's first site to present translocated traditional architecture. ${ }^{27}$ In the current area of Poland, the oldest site of this type is the museum in Wdzydze Kiszewskie, founded in $1906 .{ }^{28}$ This initiative was finalised due to much support from the Conservator of the West Prussia Province. ${ }^{29}$ At the beginning, the exhibits were gathered and displayed in a seventeenth-century arcaded house bought from local farmer, and later the other objects were translocated to the surrounding area. Similar effectiveness was exhibited by the Conservator of the East Prussia Province, who in 1913 founded the Ostpreussische Heimatmuseum in Königsberg (present-day Kaliningrad - Russia)..$^{30}$ In 1938, it was moved to larger premises in Olsztynek (current Poland). ${ }^{31}$ The vast majority of buildings presented there were copies of monuments located in the field. In 1923, Adam Chętnik accomplished the first relocation of a traditional rural cottage to Nowogród (near Łomża), where the Kurpie Museum was founded shortly after. ${ }^{32}$ In the 1930 s, the gathering of buildings also began in Kościuszko Park in Katowice. ${ }^{33}$ The design of a central museum presenting the main types of homestead from the whole area of contemporary Poland was developed during the interwar period in Warsaw. Attempts at the establishment of open-air museums also took place in Cracow and Vilnius. ${ }^{34}$

More detailed considerations on conservators' interest in mills should focus first on projects implemented in the Prussian partition. This is because the Teutonic Castle in Marienburg was one of the most important places for shaping the conservation doctrine and practice of Europe at the time. Renovation works to the castle lasted the entire nineteenth century. In the 1880s they were supervised by C. Steinbrecht. It was he who, in the years 1901-1902, erected a watermill building in the inter-wall space of the High Castle. Based on written sources,

${ }^{24}$ ZIMNA-KAWECKA, Karolina. Ochrona zabytków i organizacja urzędów konserwatorskich w Polsce okresu międzywojennego (na przykładzie woj. pomorskiego) a unormowania Ustawy z dn. 23 VII 2003 r. o ochronie zabytków i opiece nad zabytkami. In: Wiadomości Konserwatorskie, 27, 2010, p. 130.

${ }^{25}$ SPISS, Anna. Muzea etnograficæne na wolnym powietræu w Europie. Warszawa, 1985, p. 11.

${ }^{26}$ PYTLIŃSKA-SPISS, Anna. Muzea na wolnym powietrzu w Polsce. In: Etnografia Polska, 33 (2), 1989 , p. 197.

${ }^{27}$ CZAJKOWSKI, Jerzy. Muzea na wolnym powietrzu w Europie. Rzeszów-Sanok, 1984; PEDRAM, Behnam, EMAMI AMIN, Mohammad, MOZHGAN, Khakban. Role of the open-air museum in the conservation of the rural architectural heritage. In: Conservation Science in Cultural Heritage, 18, 2018, p. 101-120.

${ }^{28}$ SPISS, Murea etnograficzne..., p. 33-34.

${ }^{29}$ PRARAT, Maciej. Architektura wiejska w granicach Prus Zachodnich jako przedmiot zainteresowań naukowych i konserwatorskich do lat 40. XX w. In: Acta Universitatis Nicolai Copernici. Zabytkoznawstwo i Konserwatorstwo, XLV, 2014, p. 200-201.

${ }^{30}$ DETHLEFSEN, Richard. Ein Ostpreussisches Heimatmuseum in Königsberg.In: Denkmalpflege, 13, 1911, p. 101104.

${ }^{31}$ HISTORIA Ostpreussisches Heimatmuseum w Królewcu 1909-1945, dzisiejszego Muzeum Budownictwa Ludowego Parku Etnograficznego w Olsqtynku. Katalog wystawy. Olsztynek, 2011.

32 JASTRZEBSKI, Jerzy. Skansen Kurpiowski im. Adama Chętnika w Nowogrodzie. Lomża, 2007, p. 11.

${ }^{33}$ SPISS, Murea etnograficzne..., p. 34.

${ }^{34}$ GRABSKI, Marek. Ochrona budownictwa drewnianego. Małopolskie realizacje skansenowskie w końcu XIX $i$ w XX wieku. Kraków: Muzeum Etnograficzne im. Seweryna Udzieli w Krakowie, 2012, p. 92-142. 


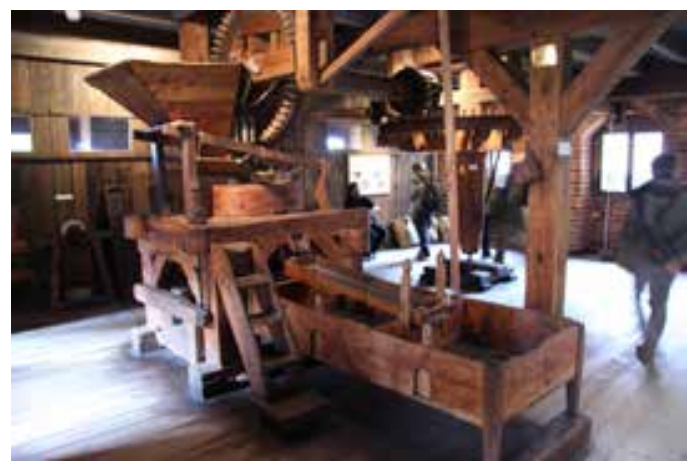

Figure 2: The equipment of a mill from 1826 on exhibition in the High Castle in Malbork (photograph by M. Prarat, 2018).

he concluded that during the medieval times there had been a functioning water-driven plant in this site. Due to the lack of any relics, the facility was designed anew. Importantly, in order to arrange the internal space, Steinbrecht purchased original equipment originating from the mills of northern Poland, including a horse mill, a mechanical mill and a shaking sieve from 1826. ${ }^{35}$ Today, this collection is considered unique at a countrywide level (fig. 2). In 1913, the Castle Rebuilding Board purchased parts of a destroyed drainage mill from Krzewsk. ${ }^{36}$ In the same year, an open-air museum was opened for sightseeing in Königsberg, having been created due to the efforts of R. Dethlefsen, a conservator of the Eastern Prussia Province. Buildings presented in it included a windmill (paltrock type) from Schönflie $\beta$, which in the 1940s was moved along with other buildings to today's open-air museum in Olsztynek. ${ }^{37}$

In the part of Poland which was under Russian and Austro-Hungarian rule in the nineteenth century, the situation was less favourable. Initiatives worth mentioning include the actions of Duke J. T. Lubomirski who, in 1875 in Warsaw, founded the Museum of Industry and Agriculture (later converted into the Museum of Technology and Industry). Not only was this facility intended to preserve monuments related to economic history, but it was also meant to conduct scientific activities, develop new technologies and establish a proper book collection. ${ }^{38}$ Already under the name Museum of Technology and Industry, it took care of objects in the field by inventorying and protecting them. In addition, it was accompanied by the shaping of an association (consisting of the representatives of various jobs) implementing and promoting the protection of technical heritage. ${ }^{39}$ In 1936, an inventory of technical and industrial monuments was initiated by the Department of Polish Architecture at the Warsaw University of Technology, which established a section of the industrial and economic building responsible for surveying inventories and photographic documentation, along with the publication of research results $^{40}$. Individual inventorying tasks were also undertaken by the previously mentioned Society for the Protection of Monuments of the Past. ${ }^{41}$

An intensification of actions related to the protection of mills took place in the second quarter of the twentieth century. However, this happened mainly on territories which remained within German boundaries. Here it is also worth recalling that the first association for the preservation of mills was established in the Netherlands in 1923. However, its actions focused

${ }^{35}$ DEUGOKECKI, Wiesław, KUCZYŃSKI, Jan, POSPIESZNA, Barbara. Mtyny w Malborku $i$ okolicy od XIII do XIX w. Malbork: Muzeum Zamkowe w Malborku, 2004, p. 91-95.

${ }^{36}$ PRARAT, Architektura wiejska..., p. 209.

${ }^{37}$ HISTORIA Ostpreussische Heimatmuseum..., p. 62, 65.

${ }^{38}$ DWUDZIESTOPIECCIOLECIE Muzeum Przemystu $i$ Rolnictwa w Warszawie 1875-1900. Warsaw, 1901, p. 3.

${ }^{39}$ JASIUK, Jerzy. Problemy ochrony zabytków techniki w Polsce. In: Ocbrona Zabytków, 18/3 (70), 1965, p. 3-12.

${ }^{40}$ KORZENIEWICZ, Władysław, ŚWIĄTECKI, Władysław. Młyn i tartak na Lemkowszczyźnie. In: Biuletyn Historii Sztuki i Kultury, 7 (1), 1939, p. 78-88; PAZDUR, Jan. Zagadnienia ochrony i konserwacji zabytków techniki. In: Ochrona Zabytków 10/2 (37), 1957, p. 114.

${ }^{41}$ The website presenting data gathered by Society for Protection of Monuments of the Past, accessed August $4^{\text {th }}, 2020$, http:// www.tonzp.dziedzictwowizualne.pl/szukaj?q=wiatrak. 


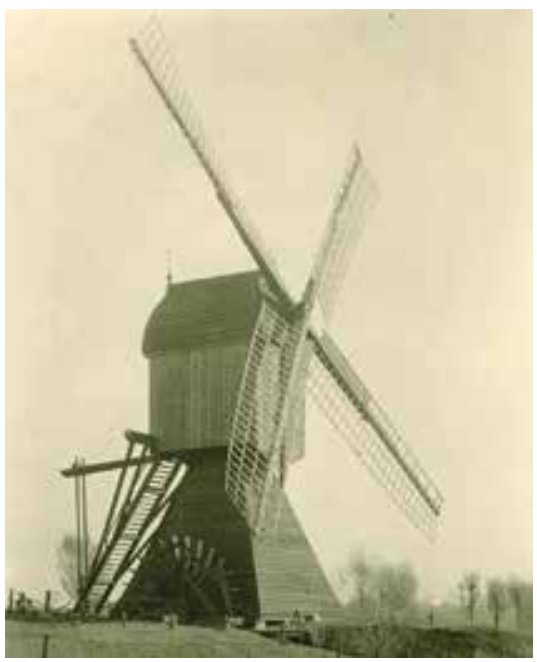

Figure 3: $A$ draining windmill in the area of Żulawy. Picture from the early twentieth century (from the resources of Marienburg Archiv, Hamburg)

more on the social desire to preserve milling traditions. Four years later, entirely different actions were undertaken by the Free City of Gdańsk, which purchased several windmills in order to protect the traditional landscape of Żulawy. At the same time, actions were taken by the West Prussia Province conservator, B. Schmid, who developed a report presenting the condition of traditional mills. In the 1930s, several more facilities were purchased due to his efforts (fig. 3). In some cases, the conservator also provided additional financing for renovations of facilities constituting private property. Such funding was granted under the condition of the high historical value of a windmill which could not be transformed. ${ }^{42}$ In hindsight, these actions should be considered as pioneering in Europe.

The situation was much worse in areas which became part of the newly reinstated Poland. Services for the protection of monuments, which were still in development, faced a different scale of problems, generally not noticing the value of technical monuments. However, this does not mean that no studies were performed in this regard during that time - examples include those related to rural industry (mainly watermills) in Podhale ${ }^{43}$ and in the Eastern Carpathians, ${ }^{44}$ Initiatives which are worth noting also include the open-air museum created by M. Znamierowska-Prüfferowa in Vilnius in 1934, in whose space the author placed fully technically operational mills. ${ }^{45}$

\section{Actions taken in the second half of the twentieth century}

The end of the Second World War is associated with a change in the state borders (cf. fig. 1), as well as the political-economic system, which largely affected the preservation of the still underestimated technical monuments. Nationalisation and subdivision of large agricultural households, performed as a result of the agricultural reform of 1944, caused numerous valuable objects to become state property, and the highly arbitrary understanding of the issue of their redevelopment resulted in the destruction and deterioration of many of them. A huge proportion of historical masonry and wooden buildings, including numerous windmills and watermills, were devastated.

The national conservation services, which were undergoing reconstitution at the time, had to face a change in borders, a new administrative division and primarily the estimation of wartime losses. The listing of monuments on a larger scale did not begin in Poland until after 1959, when it resulted from a resolution of the Government Commission on Keeping Record of

\footnotetext{
${ }^{42}$ PRARAT, Architektura wiejska..., p. 209-211.

${ }^{43}$ REYCHMAN, Jan, REYCHMAN, Stefan. Præemyst wiejski na Podhalu. Zakopane: Muzeum Tatrzańskie w Zakopanem, 1937.

${ }^{44}$ KORZENIEWICZ et al., Młyn i tartak na Lemkowszczý́nie..., p. 78-88.

${ }^{45}$ ŚWIEcCH, Jan. Ochrona młynarstwa wiejskiego w polskich muzeach na wolnym powietrzu. Założenia i realizacja. In: PRZYBYŁA-DUMIN, Agnieszka, GRABNY, Barbara, ROSZAK-KWIATEK, Paweł (eds.). Mlynarstwo tradycyjne - wczoraj, dzis, jutro... Problemy zachowania ginacego dziedzictwa. Chorzów: Muzeum „Górnośląski Park Etnograficzny w Chorzowie", 2017, p. 141.
} 
Inanimate Monuments. ${ }^{46}$ After several years, using a specially designed registration card - the so-called "green card" - the status of monuments in Poland was verified. ${ }^{47}$ Importantly, from the very beginning, conservators were already interested in wooden buildings. ${ }^{48}$ At the turn of the 1960s, the Institute of Material Culture History of the Polish Academy of Sciences worked on the "registry" of preserved technical heritage. The results of fieldwork undertaken at the time were published as the "Catalogue of Monuments of Industrial Architecture in Poland". 49

Article 5 point 6 of the Act on the Protection of Cultural Property and Museums dated 1962 includes a clause stating that protection applies to: "objects of technology and material culture, such as old mines, smelters, workshops, buildings, constructions, devices, means of transportation, machines, tools, scientific instruments and products particularly characteristic for old and modern forms of economy, technology and science, when they are unique or related to important stages of technological progress." 50

The Centre for Documentation of Monuments, which was involved in recording and documenting monuments, was also established around this time, in $1962 .{ }^{51}$ In 2002, this institution was merged with the Centre for Protection of Historical Landscape, resulting in the creation of the National Centre for Research and Documentation of Monuments. Starting from December 2010, this institution was converted into the Narodowy Instytut Dziedzictwa (National Heritage Institute - NID). The Polish Monuments Conservation Workshops Company, which functioned from the 1950s until the 1990s, was another important institution, especially in the context of performed pre-planning and planning documentation, including that of numerous mills. Activities performed by this institution included the creation of a monumental five-volume document focusing on windmills in Pomerania. ${ }^{52}$ Currently, the inventory of and supervision over monuments in Poland is carried out by voivodeship offices for the protection of monuments.

The period after the Second World War was the time when the protection of technical and industrial heritage gained more importance in Poland. This was clearly related to the ideology of promoting workers and peasants as the most important aspect of the fabric of society. ${ }^{53}$ This translated into the development of open-air museums, whose contribution to the protection of traditional milling is probably the greatest. The first open-air museum opened after the war in 1958 was the Muzeum Budownictwa Ludowego (Folk Architecture Museum) in Sanok.

\footnotetext{
${ }^{46}$ SZALYGIN, Jerzy. Rejestr i ewidencja zabytków nieruchomych oraz ruchomych w działaniach Narodowego Instytutu Dziedzictwa. In: Ocbrona Zabytków, 1-2, 2012, p. 119.

${ }^{47}$ For example: KLONOWSKI, Franciszek A. Z historii i inwentaryzacji wiatraków na Warmii, Mazurach i Powiślu. In: Rocznike Olsztynski, 1, 1958, p. 193-222; KLONOWSKI, Franciszek A. Z historii i inwentaryzacji młynów wodnych na Warmii, Mazurach i Powiślu, In: Rocznik Olsztyński, 2, 1959, p. 173-193; WESOLOWSKA, Henryka. Etnograficzne badania nad mlynarstwem wiejskim Opolszczyzny (wiatraki). Opole: Instytut Śląski w Opolu, 1961, p. 29; WESOLOWSKA, Henryka. Etnograficzne badania nad mlynarstwem wiejskim Opolszcayzny (mtyny wodne). Opole: Instytut Śląski w Opolu, 1963, p. 41.

${ }^{48}$ PRARAT, Maciej. Architektura chtopska Doliny dolnej Wisty w latach 1772-1945 i jej problematyka konserwatorska. Toruń: Muzeum Etnograficzne im. Marii Znamierowskiej-Prüfferowej w Toruniu, 2012, p. 306.

${ }^{49}$ JASIUK, Problemy ochrony..., p. 10.

${ }^{50}$ The ACT on the protection of cultural property and museums dated 15 February 1962, Journal of Laws No. 10, item 48.

${ }^{51}$ GUTTMEJER, Karol. Na czterdziestolecie Ośrodka Dokumentacji Zabytków. In: Ochrona Zabytków, 55/1 (216), 2002, p. 4-6.

${ }^{52}$ DOMAGALA, Tadeusz. Wiatraki w wojewódz̨twie gdańskim. Gdańsk, 1970-1971.

${ }^{53}$ AUGUSTYN, Agata. Dawny zakład przemysłowy jako muzeum - od idei do realizacji. Wybrane zagadnienia z ochrony dziedzictwa przemysłowego w Polsce. In: Muz̧ealnictwo, 58, 2017, p. 146.
} 
The urgent need to create this site was a result of an almost complete decline of the population of the ethnic groups of the Boykos and the Lemkosin the mountain areas of the Bieszczady and Lower Beskidy Mountains. ${ }^{54}$ The innovative concept of an open-air museum was based around the creation of sectors with fragments of village layouts. This was also the first museum into which a mill was translocated(from Wola Komborska) - this happened in $1963 .{ }^{55}$ Over the space of a dozen years (up to the end of 1979), a total of 26 windmills, nine watermills, eight oil mills, two water-powered sawmills, two fulling mills and one tannery were translocated to newly created open-air museums. ${ }^{56}$ Among the various types of mill, windmills are the ones which are most frequently translocated. In 1984, in 21 open-air museums there were already 46 windmills (including those planned for translocation in the near future).${ }^{57} \mathrm{By} 2014$, in open-air museums and at in situ protection sites that were departments of those centres, there were 55 windmills and 16 watermills. ${ }^{58}$ In all cases, there were noticeable problems involving proper exhibition, resulting directly from the lack of knowledge related to the operation of these production

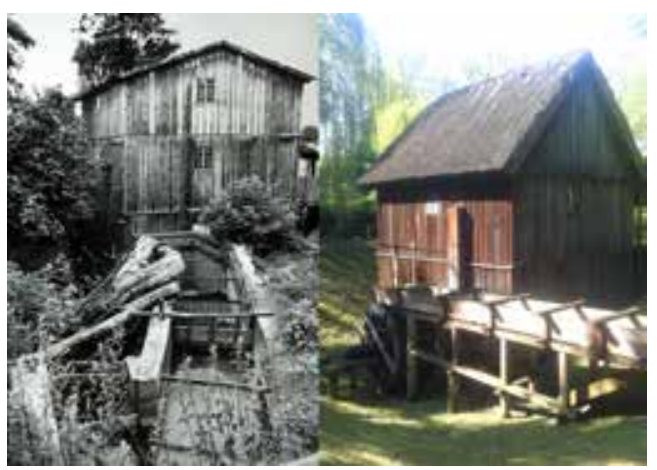

Figure 4: Watermill from Straygi with: a turbine (left - in situ in 1960s) and a overshot waterwheel (rightex situ in 2014). Currently in the Ethnographic Museum in Toruń (photograph by Archive MET, sign. I-1306-90; K. Kopczyński 2014). plants. This is why almost all of the monuments presented in museum space were not operational, and usually also lacked technological equipment.

One of the first exhibitions of the interior of a milling facility was set up in two mills (a windmill and a watermill) that were moved to the Park Etnograficzny w Toruniu (Ethnographic Park in Toruń). After the translocation of a watermill from Strzygi (fig. 4), the equipment present inside it retained its full mechanical functionality. Original machines and devices, including the arrangement of stones and the sieve, were also presented in the post mill from Wójtówka. The watermill is activated occasionally, while the windmill undergoes only maintenance rotations. The above-mentioned installations took place in the 1990s, when there were already over 40 windmills in more than 20 museums, only some of which operated using wind energy. Therefore, the cubage and possibly the equipment of the facility were preserved, but not its technical functionality, due to a lack of knowledge about how to operate the mill - that is, how to operate those elements whose necessity of preservation was pointed out as early as the 1930s by M. Znamierowska-Prüfferowa.

\section{Contemporary protection of historical mills in Poland}

Among the mills preserved up to the present day, there are very few facilities which are still

${ }^{54}$ More about the museum in: GINALSKI, Jerzy, OSSADNIK, Hubert, KROWIAK, Marcin. Muzeum Budownictwa Ludowego w Sanoku po 55 latach. In: Muzealnictwo, 54, 2013, p. 102-110; OLBERT, Patryk. Dwa skanseny na Podkarpaciu: Muzeum Budownictwa Ludowego w Sanoku i Muzeum Kultury Ludowej w Kolbuszowej. In: Rocznik Kolbuszowski, 16, 2016, p. 443.

${ }^{5}$ ŚWIECCH, Ochrona młynarstwa..., p. 141.

${ }^{56}$ CZAJKOWSKI, Jerzy. Aktualny stan prac budowlanych w muzeach na wolnym powietrzu w Polsce, In: Acta Scansenologica, 1, 1980, p. 153-154.

${ }^{57}$ SZYMAŃSKI, Adam. Udział placówek muzealnych i skansenowskich w pracach nad młynarstwem wietrznym w Polsce. In: Acta Scansenologica, 3, 1985, p. 311.

58 ŚWIĘCH, Ochrona młynarstwa..., p. 143. 
functional. The best-preserved plants are the small ones that for generations belonged to single families of millers. Some of these are mills with preserved equipment but which are no longer operational. They are activated only occasionally for local needs or for tourists. They are usually subject to informal protection by private owners or local associations.

Mills whose production equipment is not completely preserved are more common. Typically, their owners have preserved only individual devices in the form of relics. ${ }^{59}$ Their original function is generally only recognisable from their cubage, since their interiors have been given an entirely different function, such as a shop, restaurant or hotel. One popular manner of using such buildings is to take further advantage of the energy of flowing water and use them as small hydroelectric power plants. ${ }^{60}$ Unfortunately, this function does not always favour the preservation of historical equipment or the nature of the surroundings of old mills, since these objects are considered to be purely utilitarian.

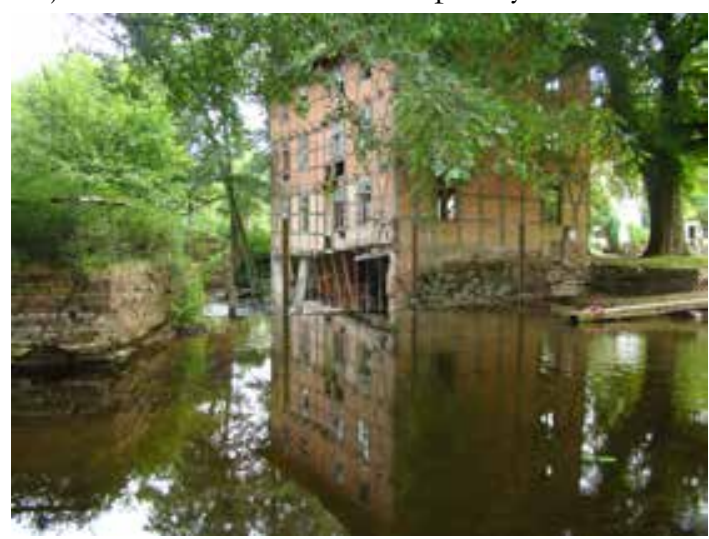

Figure 5: Condition of the watermill building in Gtębcaek (Drawsko Pomorskie County) (photograph by D. Brykała, 2011).

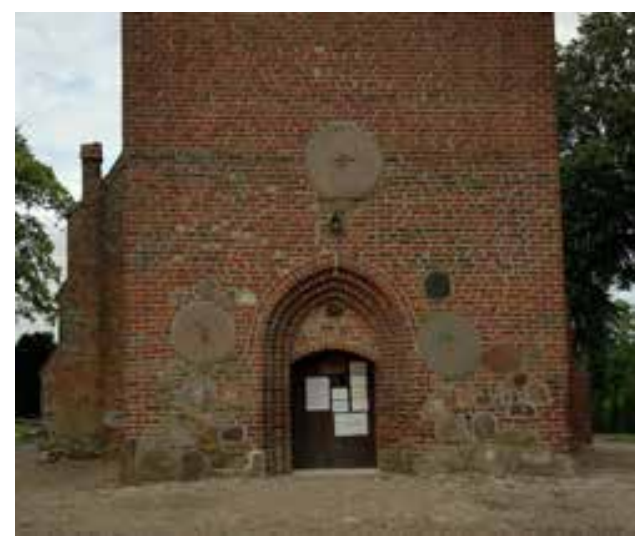

Figure 6: Three medieval millstones embedded into a wall of the Gothic church in Osieki Koszalinskie (photograph by D. Brykała, 2019).

The largest group consists of abandoned mills, ${ }^{61}$ sometimes in ruins (fig. 5). This class of mill is most noticeable in urban landscapes, in form of large milling complexes for which it is hard to find a buyer or change their function. Sometimes the mill itself no longer exists and a displayed millstone is the only relic indicating its former presence in the landscape. ${ }^{62}$ The

\footnotetext{
${ }^{59}$ See more: PRARAT, Maciej, JAGIEŁŁO, Daria. Kilka refleksji na temat badań i ochrony zabytkowych młynów w Polsce. In: PRZYBYŁA-DUMIN et al., Mtynarstwo tradycyjne - wczoraj, dqis, jutro..., p. 221-224.

${ }^{60}$ LAZDĀNE, Lilita. The historical development of watermills and small-scale hydroelectric power plants landscape in Latvia. In: Research for Rural Development, 17, 2011, p. 200-206; BRYKA£A, Dariusz, PODGÓRSKI, Zbigniew, SARNOWSKI, Łukasz, LAMPARSKI, Piotr, KORDOWSKI, Jarosław. Wykorzystanie energii wiatru i wody w okresie ostatnich 200 lat na obszarze województwa kujawsko-pomorskiego. In: Prace Komisji Krajobrazu Kulturowego, 29, 2015, p. 9-22; PUNYS, Petras, KVARACIEJUS, Algis, DUMBRAUSKAS, Antanas, ŠILINIS, Linas, POPA, Bogdan. An assessment of micro-hydropower potential at historic watermill, weir, and non-powered dam sites in selected EU countries. In: Renewable Energy, 133, 2019, p. 1108-1123.

${ }^{61}$ Compare with: BARRAUD, Régis. La rivière a ménagée et le moulin à eau. Un heritage en déshérence? Trajectoires, modèles et projets de paysage. Exemple des valléessud-armoricaines. In: Bulletin de l'Association de géographes français, 86 (1), 2009, p. 32-45; LU, Ning, LIU, Min, WANG, Rensheng. Reproducing the discourse on industrial heritage in China: reflections on the evolution of values, policies and practices. In: International Journal of Heritage Studies, 26, 2020, p. 498-518.

${ }^{62}$ BARTZ, Wojciech, PRARAT, Maciej. Results of petrographic and mineralogical research of selected millstones from Pomerania - a contribution to the use of interdisciplinary methods in research on traditional milling. In: $W i$ adomości Konserwatorskie - Journal of Heritage Conservation, 61, 2020, p. 124-144.
} 
importance and deep, symbolic meaning of millstones for local communities can be clearly seen in a fact, that some of them were even embedded into the walls of Gothic churches in Northern Poland (fig. 6).

\section{Mills in the national register of monuments}

Only some of the mills preserved until the present day are listed in the register of monuments (which results in their legal protection). Any actions taken by monument protection offices are executed based on the provisions of the act dated 23 July 2003 on the Protection of Monuments and Care for Monuments. ${ }^{63}$ According to the wording of Article 6, item 1, point 1e: regardless of their degree of preservation, protection and care apply to inanimate

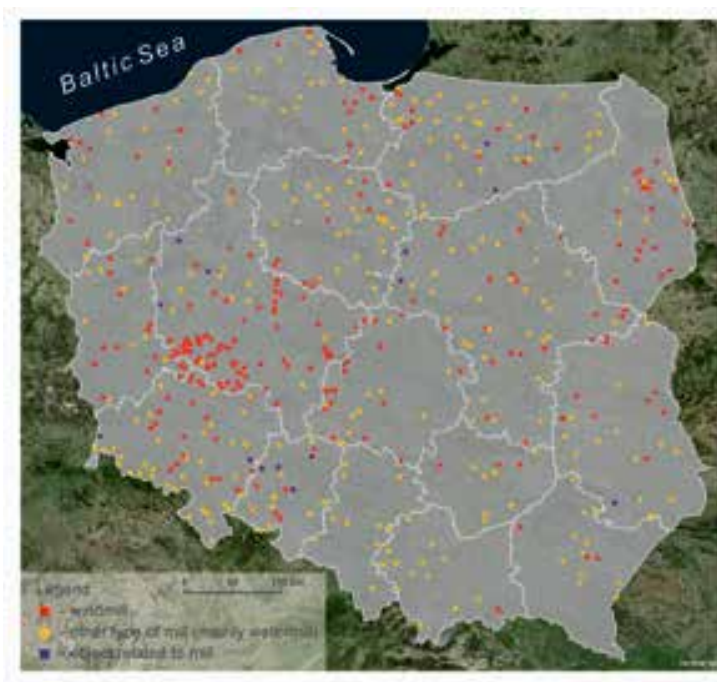

Figure 7: The distribution of mills listed in the register of inanimate monuments (Source: own compilation based on the NID data).

monuments being "technical facilities, and in particular mines, smelters, power plants and other industrial plants." ${ }^{\prime 64}$ Such a monument can be entered into the register along with its surroundings.

Currently, in the register of immovable monuments there are 576 entries $^{65}$ related to milling facilities (fig. 7). Most of them are mill buildings; however, relevant to the needs of the present paper, the list also includes several different types of monument, such as completely or partially preserved parts of mill settlements, and even a cemetery of millers. Taking into account the division by types, it has been concluded that the register includes: 254 windmills, 301 mills with different sources of propulsion (mainly water), and 21 objects closely related to milling (e.g. miller's houses etc.). 547 objects have been granted in situ protection, while ex situ protection applies to 29 milling facilities (in particular windmills) which have been translocated.

The highest number of facilities listed in the register of monuments are located in the Greater Poland Voivodeship (103), with the lowest in the Silesian Voivodeship (10). An analysis of the spatial distribution of objects in small territorial units indicated that the highest density of monuments related to milling is observed in the counties of Sokółka (Podlasie Voivodeship, 16 objects) and Leszno (Greater Poland Voivodeship, also16 objects, with three more in Leszno city county).

Greater Poland is the area of Poland with the highest abundance of historical windmills: the

\footnotetext{
${ }^{63}$ The Act dated 23 July 2003 on the Protection of Monuments and Care for Monuments (Journal of Laws 2003 No. 162, item 1568, as amended).

${ }^{64}$ Article 6 item 1 point 1 letter e of the Act dated 23 July 2003 on the Protection of Monuments and Care for Monuments (Journal of Laws 2003 No. 162, item 1568, as amended).

${ }^{65}$ In here, it should be mentioned that the term "entry" is not equivalent to an "object", since the list of inanimate monuments sometimes includes entries for objects which no longer exist (this is accompanied by a proper annotation), and some objects are referred to by more than one entry, for example because their surroundings have been added to the register.
} 
register prepared for this voivodeship includes as many as 85 mills, which is over a third of the country's resources. On the other hand, Lower Silesia Voivodeship has the highest number of historical watermills and motor mills -44 .

Due to technological issues as well as visual assets, it is important to provide for the proper display of windmills. One example illustrating the substantial significance of this parameter is the extension of the protection of a nineteenth-century windmill located in the village of Ostrowo (Strzelno municipality) to include its surroundings. The facility was listed in the register of monuments in 2004 and seven years later the lot on which it is located was also registered. ${ }^{66}$ A similar situation took place in the case of a smock mill in Wolin (Wolin municipality) - a mill entered into the register in 2001 and its surroundings in $2009 .{ }^{67}$ Unfortunately, entries that take into account hydrotechnical equipment related to a watermill are still extremely rare. Commendable exceptions include the following:

- a wooden watermill in Bondyrz (Adamów municipality) was added to the register of monuments along with its devices in $1983 ;^{68}$

- a mill in Iłowa (same municipality) was added to the register in 1992, and a water body with two weirs were added, albeit much later, in 2002 and $2003 .{ }^{69}$

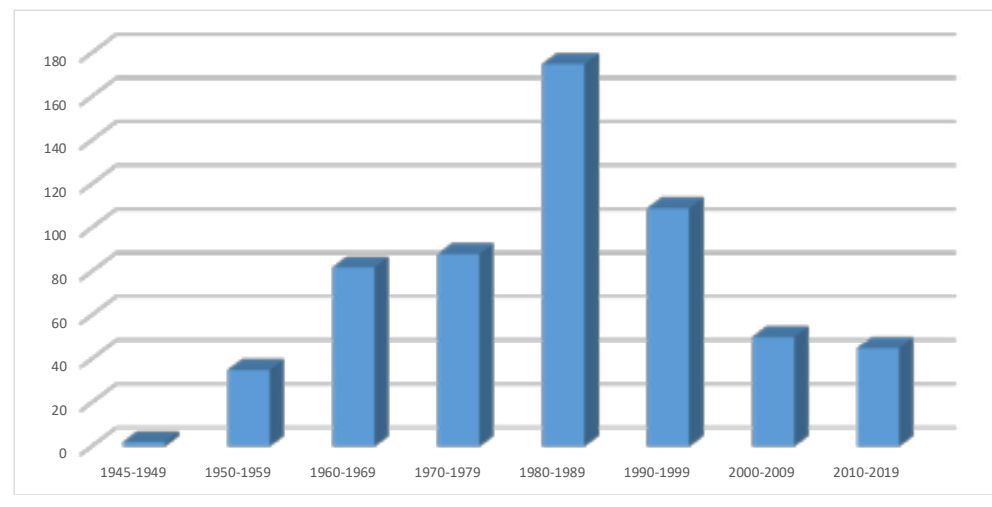

Figure 8: The number of milling facilities entered into the register of monuments after the Second World War (Source: own compilation based on the NID data)

When observing the statistics of registration of mills as monuments, it is clearly noticeable that the highest number of entries was recorded in the 1980s and 1990s (fig. 8). The issue of practical actions taken by officials gives quite a different perspective. In recent years, there has been a visible number of actions involving monuments which usually belong to municipalities and towns. Unfortunately, the lack of expert knowledge in this regard among official conservators and primarily contractors very frequently results in the destruction of monuments under the guise of improving their condition. This is of especial concern with windmills in which

\footnotetext{
${ }^{66}$ Register of immovable monuments of Kujawsko - Pomorskie voivodeship published on website of National Heritage Institute, accessed August $4^{\text {th }}, 2020$, https://www.nid.pl/pl/Informacje_ogolne/Zabytki_w_Polsce/rejestr-zabytkow/zestawienia-zabytkow-nieruchomych/stan \%20na\%2030.06.2019/KUJ-rej.pdf.

${ }^{67}$ Register of immovable monuments of Zachodniopomorskie voivodeship published on website of National Heritage Institute, accessed August 4 ${ }^{\text {th }}, 2020$, https://www.nid.pl/pl/Informacje_ogolne/Zabytki_w_Polsce/rejestr-zabytkow/zestawienia-zabytkow-nieruchomych/stan\%20na\%2030.06.2019/ZPO-rej.pdf.

${ }^{68}$ Register of immovable monuments of Lubelskie voivodeship published on website of National Heritage Institute, accessed August $4^{\text {th }}, 2020$, https://www.nid.pl/pl/Informacje_ogolne/Zabytki_w_Polsce/rejestr-zabytkow/zestawienia-zabytkow-nieruchomych/stan\%20na\%2030.06.2019/LBL-rej.pdf.

${ }^{69}$ Register of immovable monuments of the Lubuskie Voivodeship published on the website of the National Heritage Institute, accessed August $4^{\text {th }}, 2020$, https://www.nid.pl/pl/Informacje_ogolne/Zabytki_w_Polsce/rejestr-zabytkow/zestawienia-zabytkow-nieruchomych/stan\%20na\%2030.06.2019/LBS-rej.pdf.
} 


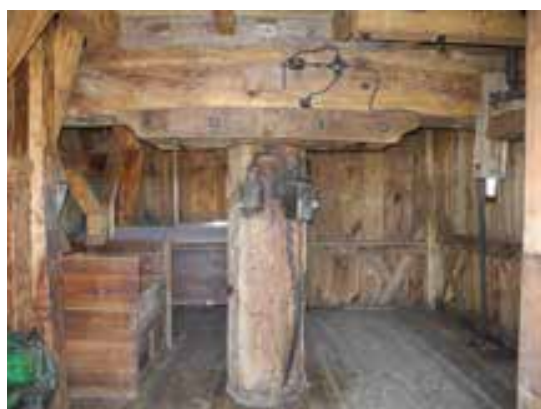

Figure 9: The interior of the windmill from structure been preserved, but also - due to the possibility Leszno after conservation works (photograph of rotating the building and the wing shaft - the full techby M. Prarat, 2018)

most of historical structure is replaced without restoring its technical functionality.

One of the few exceptions presenting a reasonable approach to conservation as well as high quality of craftsmanship is the operation involving the windmill in Leszno (fig. 9), performed under the supervision of the Office of the City Conservator of Monuments. This monument was moved onto the premises of an agricultural school. Not only has the vast majority of its eighteenth-century nical functionality of the windmill has been restored. Its equipment in turn reflects technological changes in the profession of milling.

\section{Actions for the preservation of mills undertaken by museums}

In 41 locations listed among 31 Polish open-air museums (fig. 10), 71 windmills and 22 watermills are currently on exhibition. ${ }^{70}$ Objects originating from the nineteenth century prevail among watermills (almost half of the total number), with objects built in the twentieth century prevalent among windmills (almost half of the total number). Most of them have been relocated to open-air museums, where they have undergone thorough renovation (fig. 11). A post mill relocated from Gryżyna near Kościan to the Muzeum Pierwszych Piastów na Lednicy (Museum of First Piasts on Lake Lednica) has the oldest construction element in Poland, dated 1585. The oldest watermill displayed in open-air museums was built in 1832 in Stare Siołkowice and relocated to the Muzeum Wsi Opolskiej (Museum of the Opole Villages) in Bierkowice.

Usually, an open-air museum displays one mill (although many museums still do not have them at all). The institution with the most mills is the Muzeum Kultury Ludowej w Kolbuszowej (Folk Culture Museum in Kolbuszowa), which houses one watermill (with an undershot waterwheel) and seven windmills (four post mills, one paltrock and two smock mills). It is followed by the Muzeum Wsi Kieleckiej (Museum of the Kielce Villages) in Tokarnia and Szwarszowice, which displays two watermills (with overshot waterwheels) and six windmills (including two post mills, one paltrock and foursmock mills). Unfortunately, not even a reconstruction of a floating mill has been preserved in any Polish open-air museums. In the past, hundreds of such mills operated on large navigable rivers, ${ }^{71}$ but today not even a trace of them is left. A chance for it presented itself when a boat mill, reconstructed in 2013, was displayed in the Museum of the Kielce Villages in Tokarnia. Unfortunately, the exhibition only lasted for four years.

The total number of mills presented in open-air museums is small, and moreover (maybe even more importantly), the quality of presentation of these monuments is very low, with problems ranging from the possibilities to their interior design.

Currently in Poland there are two places which can be considered milling museums. The first one is the Muzeum Młynarstwa i Wodnych Urządzeń Przemysłu Wiejskiego w Jaraczu (Museum of Milling and Hydrotechnical Devices of the Rural Industry in Jaracz), a branch

\footnotetext{
${ }^{70}$ Compare with: ŚWIĘCH, Ochrona młynarstwa..., p. 143.

${ }^{71}$ SZUROWA, Bogumiła. Młyny pływające na Nidzie i Wiśle w XVIII i XIX w Kieleckiem. In: Kielecka Teka Skansenowska, 2, 2002, p. 97-130; BRYKAŁA, Dariusz, PRARAT, Maciej. Reconstruction of boat mills distribution on the Drwęca river and Pomeranian part of the Vistula River in the early nineteenth century. In: Prace Komisji Krajobrazu Kulturowego, 40, 2018, p. 71-89.
} 


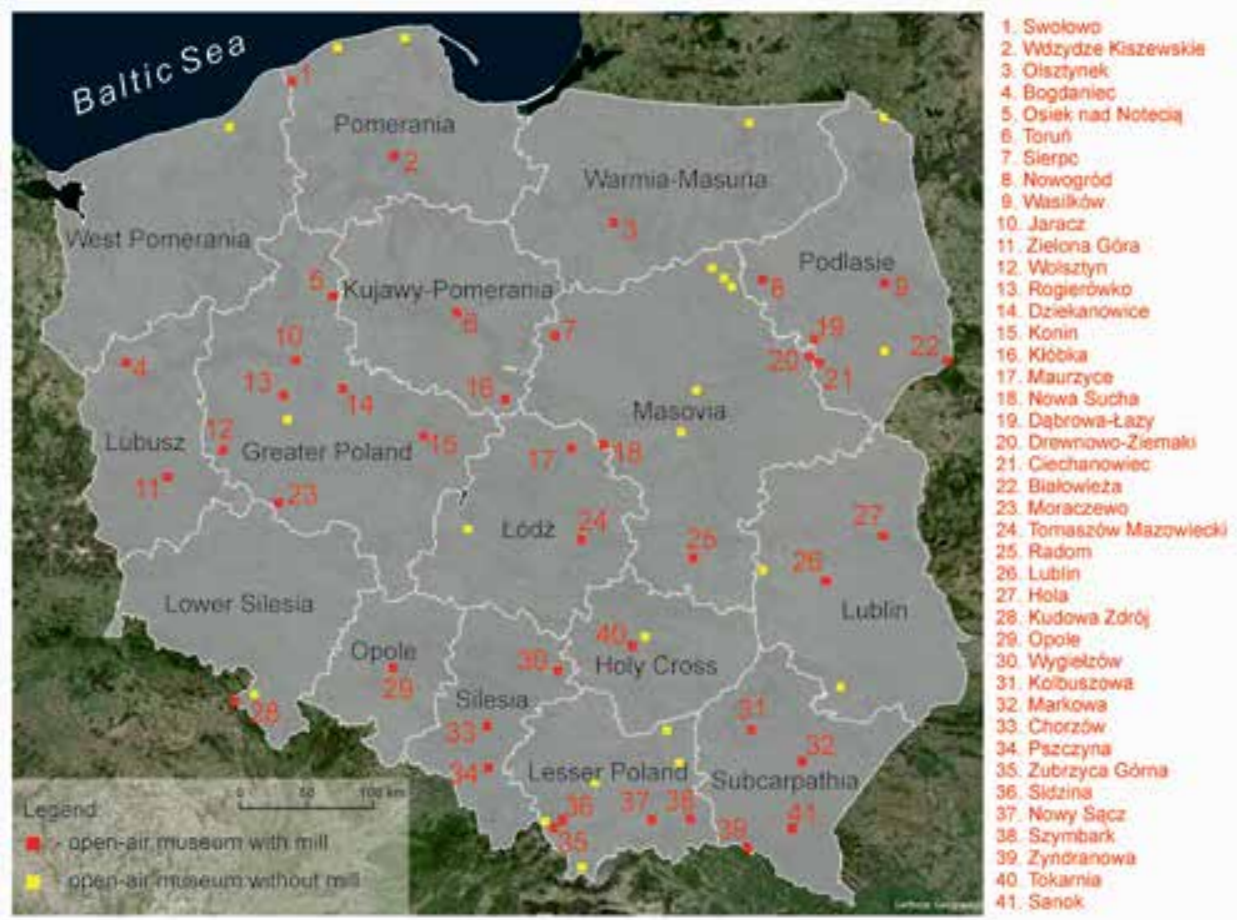

Figure 10: Open-air museums in Poland, including sites presenting mills (Source: own compilation).

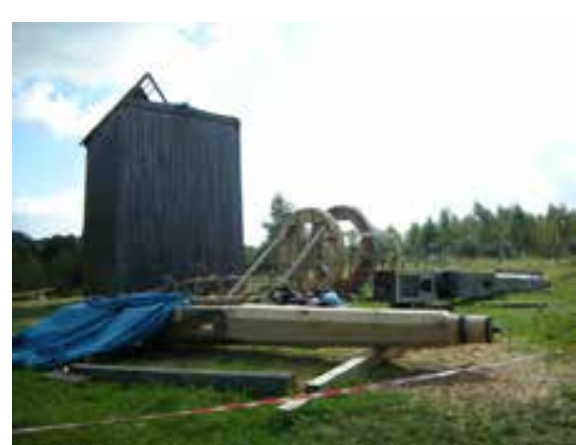

Figure 11: Post mill in the Kujawsko-Dobrsynnski Ethnographic Park in Kłóbka, during conservation works (photograph by M. Prarat 2009)

of the Muzeum Narodowe Rolnictwa i Przemysłu Rolno-Spożywczego w Szreniawie (National Museum of Agriculture and Agricultural and Food Industry in Szreniawa). It is located near a once-functioning watermill. Today, a hydroelectric power plant operates there, while the interiors have retained most of their equipment. On the other hand, the post mill translocated to the museum from Czacz looks unimpressive. Most of its elements have been replaced, while the mill itself is not functional. Therefore, no milling devices can be seen at this site! The situation is even worse in the private Muzeum Młynarstwa i Rolnictwa w Osiecznej (Museum of Milling and Agriculture in Osieczna), where all windmills have been immobilised, while their interiors display exhibitions which have nothing to do with milling.

Considering the above, the historical forge located by the Oliwa Brook remains an isolated good example. This facility with a very archaic layout was active until 1947. In the 1950s, the monument was taken over by the Muzeum Techniki (Museum of Technology) in Warsaw and the forge was reactivated in $1978 .^{72}$ It was one of few monuments driven by water which were fully functional and available for sightseeing. It was closed in 2017 for planned renovation when

\footnotetext{
${ }^{72}$ MAJEWSKI, Wojciech. Zabytkowa kuźnia wodna na Potoku Jelitkowskim. In: KLIM, Roman (ed). Materiały I sympozjum Zabytki bydrotechniki w Polsce. Gdańsk: Gdański Oddział Towarzystwa Opieki nad Zabytkami, Centralne Muzeum Morskie, 1996, p. 84-91.
} 
the city of Gdańsk became its owner. After the renovation is complete, this monument will be made accessible for sightseeing again.

Another monumental complex originally driven by the energy of water is the Paper Mill in Duszniki, whose oldest fragments date back to the sixteenth century. The museum dedicated to the production of paper established inside it has applied for inclusion on the UNESCO List of World Heritage Sites. ${ }^{73}$

One of the most significant initiatives of recent years involving the protection of milling heritage is the creation of a museum at Hilbert's Mill in Dzierżoniów, one of the largest flour-producing plants in Silesia. The mill was modernised before the Second World War, when it was given electric propulsion. Unmodified since then, it was turned directly from a production facility into a museum exhibit. ${ }^{74}$

It turns out that the current main problem of museums is not so much the actual process of translocating or establishing protection over technical monuments, but the establishment of effective procedures aimed at their reactivation. This problem results not just from the lack of professional mill constructors in Poland, but also from the lack of millers familiar with working in traditional facilities. For example, the smock mill translocated to the Muzeum Kaszubski Park Etnograficzny (Museum - Kaszuby Ethnographic Park) in Wdzydze Kiszewskie from Brusy in 1994, remains fully functional. ${ }^{75}$ However, today there is no longer anyone who can operate it. Attention should be paid to actions taken in the recent years in the Muzeum "Górnośląski Park Etnograficzny w Chorzowie" (Museum of "Upper Silesian Ethnographic Park in Chorzów"), where (although driven by electric motors) the mills keep grinding grain for educational purposes. ${ }^{76}$ The visitors can watch the entire production process. A group of people meet here to help with operating the devices and carry outfield inventories.

Two important institutions for dissemination of knowledge about mills are the previously mentioned museums in Torun and Jaracz. The latter has been organising regular meetings of milling enthusiasts since 2011. ${ }^{77}$ In 2016 and 2017, another group of enthusiasts organised the Day of Mills, famous all over Europe; unfortunately, this event has since been discontinued. However, there are still attempts being made to promote the heritage connected to milling, including by establishing a national society and integrating it with international organizations such as The International Molinological Society.

Therefore, recent years have seen intense verification of the number of historical mills and related objects, and attempts are being made to maintain or restore their operability and functionality. Endeavours are also being made to promote knowledge about mills among the

\footnotetext{
${ }^{73}$ EYSYMONTT, Rafał, SACHS, Rainer, SZYMCZYK, Maciej. Młyn papierniçyy w Dusznikach-Zdroju. Duszniki Zdrój: Muzeum Papiernictwa w Dusznikach Zdroju, 2018, p. 19-35.

${ }^{74}$ Website about Hilbert's Mill, accessed August 4 ${ }^{\text {th }}, 2020$, https://www.muzeatechniki.pl/obiekty/mlyn-hilberta/.

${ }^{75}$ SADKOWSKI, Tadeusz. Katalog tradycyjnego budownictwa w Muzeum - Kaszubskim Parku Etnograficznym we Wdzydzach. Wdzydze Kiszewskie: Muzeum Kaszubski Park Etnograficzny we Wdzydzach Kiszewskich, 2018, p. 171-179.

${ }^{76}$ ROSZAK-KWIATEK, Paweł. Młynarstwo tradycyjne ginący zawód? Sprawozdanie z wyjazdu do Wielkiej Brytanii 20.08.-28.08. 2014 r. In: Rocznik. Muzeum Górnoślaski Park Etnograficzny w Chorzowie, 2, 2014, p. $240-261$.

${ }^{77}$ Website of the Milling Musem in Jaracr, accessed: August $4^{\text {th }}, 2020$, http://www.muzeum-szreniawa.pl/imuzeum/ web/app.php/vortal/muzeum_mlynarstwa_w_jaraczu/spotkania_milosnikow_wiatrakow_i_mlynow_wodnych. html
} 
teachers of environmental and historic subjects ${ }^{78}$ as well as scientists. ${ }^{79}$

\section{Summary}

Actions taken in order to protect mills in the current territory of Poland date back to the nineteenth century and they had a pioneering nature for all of Europe. During the period after the Second World War, when the situation favoured the preservation of monuments of technology and material culture, no attention was paid to the possibility that these mills might once again perform their traditional production tasks. Ninety years after the first such implementation, this is slowly once again becoming the main purpose of preservation work performed on mills. The mere $3.4 \%$ of facilities entered into the Register of Monuments as functioning at the beginning of the twentieth century should be considered highly insufficient from the standpoint of their significance for the cultural landscape of Poland, and the level of attempted conservation work involving these objects should be considered unsatisfactory. ${ }^{80}$ Even more so, one should point out the role of open-air museums in the need to retain the original functionality of mills. ${ }^{81}$

Regardless of conservation actions, attempts are being made to catalogue information about mills, both for watermills ${ }^{82}$ and windmills, ${ }^{83}$ both of which are considered to be objects of cultural heritage. ${ }^{84}$ Such actions are initiated by both researchers and the representatives of other groups interested in milling, such as hobbyists.

\section{Acknowledgements}

This study was supported by the Narodowe Centrum Nauki (National Science Centre), Kraków, Poland (grant numbers: 2011/03/D/HS3/03631, project Mtyny wodne w dorzeczu dolnej Wisty od poczqtku XVIII do poczqtku XXI wieku' - 'Watermills in lower Vistula catchment area from the early 18th century to the early 21st century' and 2019/35/B/HS3/03933, project 'Pamiec kamieni. Pochodzenie, użytkowanie $i$ sakralizacja kamieni mlynskich wmurowanych w ściany gotyckich kościotów na Nizinach Potudniowobattyckich' - 'The memory of stones. Origin, use and sacralization of millstones embedded in walls of Gothic churches within the Southern Baltic Lowlands') and by the Kazimierz Wielki University in Bydgoszcz (grant number BS/2016/K2, project 'Ewolucja i mechanizm zmian krajobrazu pod wplywem driałalności człowieka' - 'Evolution and mechanism of changes in landscape caused by human

\footnotetext{
${ }^{78}$ BIELECKA, Danuta, KOCHAŃSKA-BAYER, Anna, KORDALSKA, Aurelia, KATER, Wojciech, LIPKA, Stefan, PAJAॄKOWSKI, Cezary. Młyn wodny przykładem środowiska do interdyscyplinarnej edukacji przyrodniczej. In: Nauczanie Przedmiotów Pryyrodniczych, 3, 2001, p. 10-14.

${ }^{79}$ PRARAT et al., Kilka refleksji..., p. 226.

${ }^{80}$ Compare with: MLYNKA, Ladislav. Mlyny na Slovensku, typológia a historicko-etnografická charakteristika. In: DANTEROVÁ, Izabela (ed.). Mlyny a Mlynárske Remeslo, Etnograf a Múreum, ročník 10, Galanta: Vlastivedné múzeum v Galante, 2006, p. 7-20.

${ }^{81}$ BRYKAŁA, Dariusz, PRARAT, Maciej, JAGIEŁLO, Daria. Watermills and windmills in open air museums within the Kujawsko-Pomorskie Region (in Poland) and their conservation issues. In: TIMS 14th Symposium 2015 Transactions, Sibiu, 2018, p. 461-474.

${ }^{82}$ GOLASKI, Janusz. Atlas rozmieszczenia mlynów wodnych w dorzeczach Warty, Brdy i czésci Baryçy w okeresie 1790-1960. Cz. I. Środkowa Warta, Prosna i Barycz. Poznań: Akademia Rolnicza w Poznaniu, 1980; MOSAKOWSKI, Zachariasz, BRYKAŁA, Dariusz. Types of watermills on Polish rivers - assumptions in the CeBaDoM database. In: World Scientific News, 131, 2019, p. 75-87.

${ }^{83}$ Website about windmills in Poland, accessed August 4th, 2020, http://www.wiatraki.org.pl/.

${ }^{84}$ GLASER-OPITZ, et al.,Vodné mlyny na Slovensku..., p. 67-76; CHERNYH, Olga N., VOLSHANIK, Valerij $\mathrm{V}$. Rol vodyanyh melnits v vossozdanii istoricheskih landshaftov (Role of watermills in restoration historical landscapes). In: Prirodoobustrojstvo, 4, 2017, p. 47-55 [in Russian].
} 
activity'). The resultant spatial database of mills will be available in the Centralna Baza Danych o Młynach w Polsce (Central Database of Mills in Poland CeBaDoM, currently in preparation). Its dissemination proceeds on the platform http://rcin.org.pl/, under the implementation of the Otwarte Zasoby Naukowe w Reposytorium Cyfrowym Instytutów Naukowych (Open Scientific Resources project in the Digital Repository of Scientific Institutes OZwRCIN), financed from the European Funds and the state budget under the Program Operacyjny Polska Cyfrowa (Digital Poland Operational Programme) subaction 2.3.1 'Cyfrowe udostepnianie informacji sektora publicznego ze źródeł administracyjnych $i$ zasobów nauki' -'Digital sharing of public sector information from administrative sources and scientific resources' (grant number POPC.02.03.01-00-0029/17).

\section{References}

ARSZYŃSKI, Marian (2007). Idea, pamię́, troska. Rola zabytków w przestrzeni spotecznej i formy działan na rzeczich zachowania od starożytności do potowy XX w. Malbork: Wydawnictwo Muzeum Zamkowego w Malborku. ISBN 9788360518090.

AUGUSTYN, Agata (2017). Dawny zakład przemysłowy jako muzeum - od idei do realizacji. Wybrane zagadnienia z ochrony dziedzictwa przemysłowego w Polsce. In: Muzealnictwo, 58, p. 143-154. ISSN 0464-1086.

BARANOWSKI, Bohdan (1977). Polskie mlynarstwo. Wrocław: Ossolineum.

BARRAUD, Régis (2009). La rivière aménagée et le moulin à eau. Un héritage en déshérence? Trajectoires, modèles et projets de paysage. Exemple des vallées sud-armoricaines. In: Bulletin de l'Association de géographes français, 86 (1), p. 32-45. ISSN 0004-5322.

BARTZ, Wojciech, PRARAT, Maciej (2020). Results of petrographic and mineralogical research of selected millstones from Pomerania - a contribution to the use of interdisciplinary methods in research on traditional milling. In: Wiadomości Konserwatorskie - Journal of Heritage Conservation, 61, p. 124-144. ISSN 0860-2395.

BIELECKA, Danuta, KOCHAŃSKA-BAYER, Anna, KORDALSKA, Aurelia, KATER, Wojciech, LIPKA, Stefan, PAJAKOWSKI, Cezary (2001). Młyn wodny przykładem środowiska do interdyscyplinarnej edukacji przyrodniczej. In: Nauczanie Przedmiotów Prayrodniczych, 3, 2001, p. 10-14. ISSN 1509-6351.

BLOCH, Marc (1935). Avènement et Conquêtes du Moulin a Eau. In: Annales d'histoire économique et sociale, 7/36, p. 538-563. ISSN 0003-441X.

BRAUDEL, Fernand (1986). L'identité de la France, Vol. 3, Paris: Arthaud-Flammarion. ISBN 2700305957

BRYKAŁA, Dariusz (2001). Uwarunkowania przyrodnicze lokalizacji młynów wodnych w zlewni Skrwy. In: GERMAN, Krystyna \& BALON, Jarosław (eds). Prz̧emiany środowiska prayyrodniczego Polski a jego funkecjonowanie. Kraków: Instytut Geografii i Gospodarki Przestrzennej UJ. p. 164-171. ISBN 83-88424-11-4

BRYKALA, Dariusz, PODGÓRSKI, Zbigniew (2020). Evolution of landscapes influenced by watermills, based on examples from Northern Poland. In: Landscape and Urban Planning, 198, article No. 103798. ISSN 0169-2046.

BRYKALA, Dariusz, PODGÓRSKI, Zbigniew, SARNOWSKI, Lukasz, LAMPARSKI, Piotr, KORDOWSKI, Jarosław (2015). Wykorzystanie energii wiatru i wody w okresie ostatnich 200 lat na obszarze województwa kujawsko-pomorskiego. In: Prace Komisji Krajobrazu Kulturowego, 29, p. 9-22. ISSN 1896-1460.

BRYKALA, Dariusz, PRARAT, Maciej, JAGIEŁŁO, Daria (2018). Watermills and windmills in open air museums within the Kujawsko-Pomorskie Region (in Poland) and their conservation issues. In: TIMS 14th Symposium 2015 Transactions, Sibiu, p. 461-474. ISBN 978-606- 
733-252-0.

BRYKAŁA, Dariusz, PRARAT, Maciej (2018). Reconstruction of boat mills distribution on the Drwęca river and Pomeranian part of the Vistula River in the early nineteenth century. In: Prace Komisji Krajobrazu Kulturowego, 40, p. 71-89. ISSN 1896-1460.

CHERNYH, Olga N.,VOLSHANIK, Valerij V. (2017). Rol vodyanyh melnits v vossozdanii istoricheskih landshaftov (Role of watermills in restoration historical landscapes). In: Prirodoobustrojstvo, 4, p. 47-55. [in Russian] ISSN 1997-6011.

ÇORAPÇIOĞLU, Gülferah (2016). Conservation of the traditional water mills in the Mediterranean Region of Turkey. In: Journal of Cultural Heritage Management and Sustainable Development, 6 (3), p. 287-315. ISSN 2044-1266.

CZAJKOWSKI, Jerzy (1980). Aktualny stan prac budowlanych w muzeach na wolnym powietrzu w Polsce. In: Acta Scansenologica, 1, p. 147-156. ISBN 0208-8053.

CZAJKOWSKI, Jerzy (1984). Mužea na wolnym powietrž w Europie. Rzeszów-Sanok. ISBN 8303-00527-8.

DEMBIŃSKA, Maria (1973). Pržetwórstwo z̧bożowe w Polsce średniowiecznej (X-XIV wiek). Wrocław: Ossolineum.

DETHLEFSEN, Richard (1911). Ein Ostpreussisches Heimatmuseum in Königsberg. In: Denkmalpflege, 13, p. 101-104. ISSN 1864-5062

DETTLOFF, Paweł (2006). Odbudowa i restauracja zabytków architektury w Polsce w latach 1918 1939. Teoria i praktyka. Kraków: Towarzystwo Autorów i Wydawców Prac Naukowych UNIVERSITAS. ISBN 83-242-0778-3.

DŁUGOKĘCKI, Wiesław, KUCZYŃSKI, Jan, POSPIESZNA, Barbara (2004). Młyny w Malborku $i$ okolicy od XIII do XIX w. Malbork: Muzeum Zamkowe w Malborku. ISBN 8386206705.

DWUDZIESTOPIECIOLECIE Muzeum Przemystu i Rolnictwa w Warsqawie 1875-1900. (1901). Warszawa: Muzeum Przemysłu i Rolnictwa w Warszawie.

DZIK, Antoni (1928). Młynarstwo w Polsce. Warszawa: Nakładem Związku Młynarzy Polskich.

EYSYMONTT, Rafal, SACHS, Rainer, SZYMCZYK, Maciej (2018). Młyn papierniczy w Dusznikach-Zdroju. Duszniki Zdrój: Muzeum Papiernictwa w Dusznikach Zdroju. ISBN 8360990395.

FAJER, Maria (2014). Watermills, a Forgotten River Valley Heritage, selected examples from the Silesian voivodeship, Poland. In: Environmental \& Socio-economic Studies, 2 (2), p. 1-9. ISSN 2354-0079.

FRYCZ, Jerzy (1975). Restauracja i konserwacja zabytków architektury w Polsce w latach 1795-1918. Warszawa: Państwowe Wydawnictwo Naukowe.

GINALSKI, Jerzy, OSSADNIK, Hubert, KROWIAK, Marcin (2013). Muzeum Budownictwa Ludowego w Sanoku po 55 latach. In: Murealnictwo, 54, p. 102-110. ISSN 0464-1086.

GLASER-OPITZ, Zoltán, KULLA, Marián, SPIŠIAK, Peter (2012). Vodné mlyny na Slovensku ako fenomen kultúrneho dedičstva. In: Geografické Informácie, 16 (1), p. 67-76. ISSN 1337-9453.

GOLASKI, Janusz (1980). Atlas rozmieszczenia mlynów wodnych w dorzeczach Warty, Brdy i cześsi Baryczy w okresie 1790-1960. Cz. I. Środkowa Warta, Prosna i Barycz: Poznań: Akademia Rolnicza w Poznaniu.

GRABSKI, Marek (2012). Ochrona budownictwa drewnianego. Małopolskie realizacje skansenowskie w końcu XIX $i$ w XX wieku. Kraków: Muzeum Etnograficzne im. Seweryna Udzieli w Krakowie. ISBN 9788376381879.

GUTTMEJER, Karol (2002). Na czterdziestolecie Ośrodka Dokumentacji Zabytków. In: Ochrona Zabytków, 55/1 (216), p. 4-13. ISSN 0029-8247.

HEYMANN, Mathias (1995). Die Geschichte der Windenergienutzung: 1890-1990. Frankfurt/ 
Main-New York: Campus Verlag. ISBN 3539352788.

HISTORIA Ostpreussisches Heimatmuseum w Królewcu 1909-1945, dzisiejszego Muzeum Budownictwa Ludowego Parku Etnograficznego w Olsztynku. Katalog wystawy. (2011). Olsztynek: Muzeum Budownictwa Ludowego Parku Etnograficznego w Olsztynku. ISBN 8393087325.

JASIUK, Jerzy (1965). Problemy ochrony zabytków techniki w Polsce. In: Ochrona Zabytków, $18 / 3$ (70), p. 3-12. ISSN 0029-8247.

JASTRZĘBSKI, Jerzy (2007). Skansen Kurpiowski im. Adama Chetnika w Nowogrodzie. Łomża. ISBN 978-83-87108-35-9.

JOKILEHTO, Jukka (1999). A History of Architectural Conservation. New York: Routledge. ISBN 0750637935.

KLONOWSKI, Franciszek A. (1958). Z historii i inwentaryzacji wiatraków na Warmii, Mazurach i Powiślu. In: Rocznike Olsztyński, 1, pp. 193-222. ISSN 0080-3537.

KLONOWSKI, Franciszek A. (1959). Z historii i inwentaryzacji młynów wodnych na Warmii, Mazurach i Powiślu, In: Rocznike Olsztyński, 2, p. 173-193. ISSN 0080-3537.

KORZENIEWICZ, Władysław, ŚWIĄTECKI Władysław (1939). Młyn i tartak na Łemkowszczyźnie. In: Biuletyn Historii Sztuki i Kultury, 7 (1), p. 78-88. ISSN 0006-3967.

LAZDĀNE, Lilita (2011). The historical development of watermills and small-scale hydroelectric power plants landscape in Latvia. In: Research for Rural Development, 17, p. 200-206. ISSN 1691-4031.

LEVEAU, Philippe (1996). The Barbegal water mill in its environment: archaeology and the economic and social history of antiquity. In: Journal of Roman Archaeology, 9, p.137-153. ISSN 1047-7594.

LEZIUS, Hermann (1908). Das Recht der Denkmalpflege in Preussen. Berlin.

LU, Ning, LIU, Min, WANG, Rensheng (2020). Reproducing the discourse on industrial heritage in China: reflections on the evolution of values, policies and practices. In: International Journal of Heritage Studies, 26 (5), p. 498-518. ISSN 1352-7258.

LUCAS, Adam (2005). Industrial Milling in the Ancient and Medieval Worlds. A Survey of the Evidence for an Industrial Revolution in Medieval Europe. In: Technology and Culture, 46 (1), p. 1-30. ISSN 0040-165X.

MAJEWSKI, Wojciech (1996). Zabytkowa kuźnia wodna na Potoku Jelitkowskim. In: KLIM, Roman (ed). Materiaty I sympozjum Zabytki bydrotechniki w Polsce. Gdańsk: Gdański Oddział Towarzystwa Opieki nad Zabytkami, Centralne Muzeum Morskie, p. 84-91.

MLYNKA, Ladislav (2006). Mlyny na Slovensku, typológia a historicko-etnografická charakteristika. In: DANTEROVÁ, Izabela (ed.). Myyy a Mlynárske Remeslo, Etnograf a Múzeum, ročník 10, Galanta: Vlastivedné múzeum v Galante, p. 7-20. ISBN 80-969062-3-2

MOSAKOWSKI, Zachariasz, BRYKA£A, Dariusz (2019). Types of watermills on Polish rivers, assumptions in the CeBaDoM database. In: World Scientific News, 131, p. 75-87. eISSN 2392-2192.

OLBERT, Patryk (2016). Dwa skanseny na Podkarpaciu: Muzeum Budownictwa Ludowego w Sanoku i Muzeum Kultury Ludowej w Kolbuszowej. In: Rocznik Kolbuszowski, 16, p. 441453. ISSN 0860-4584.

OLIVER, Stuart (2013). Liquid materialities in the landscape of the Thames: mills and weirs from the eighth century to the nineteenth century. In: Area, 45 (2), p. 223-229. ISSN 00040894.

PAWLIK, Mieczysław (1984). Wiatraki pótnocno-wschodniej Polski. Rozprawy Uniwersytetu Warszawskiego, 273, Białystok: Uniwersytet Warszawski. ISSN 0509-7177

PAZDUR, Jan (1957). Zagadnienia ochrony i konserwacji zabytków techniki. In: Ochrona Zabytków, 10/2 (37), p. 113-122. ISSN 0029-8247.

PEDRAM, Behnam, EMAMI AMIN, Mohammad, MOZHGAN, Khakban (2018). Role of 
the open-air museum in the conservation of the rural architectural heritage. In: Conservation Science in Cultural Heritage, 18, p. 101-120. ISSN 1974-4951.

PRARAT, Maciej, JAGIEŁŁO, Daria. Kilka refleksji na temat badań i ochrony zabytkowych młynów w Polsce. In: PRZYBYŁA-DUMIN, Agnieszka, GRABNY, Barbara, ROSZAK -KWIATEK, Paweł (eds.). Mtynarstwo tradycyjne - wczoraj, dzis, jutro... Problemy zachowania ginacego dziedzictwa. Chorzów: Muzeum „Górnośląski Park Etnograficzny w Chorzowie”, p. 215-232. ISBN 978-83-948607-2-1.

PRARAT, Maciej (2012). Architektura chtopska Doliny dolnej Wisty w latach 1772-1945 i jejproblematyka konserwatorska. Toruń: Muzeum Etnograficzne im. Marii Znamierowskiej-Prüfferowej w Toruniu. ISBN 978-83-61891-40-6.

PRARAT, Maciej (2014). Architektura wiejska w granicach Prus Zachodnich jako przedmiot zainteresowań naukowych i konserwatorskich do lat 40. XX w. In: Acta Universitatis Nicolai Copernici. Zabytkoznawstwo i Konserwatorstwo, 45, p. 185-223. ISSN 0208-533X.

PUNYS, Petras - KVARACIEJUS, Algis - DUMBRAUSKAS, Antanas - ŠILINIS, Linas POPA, Bogdan (2019). An assessment of micro-hydropower potential at historic watermill, weir, and non-powered dam sites in selected EU countries. In: Renewable Energy, 133, p. 1108-1123. ISSN 0960-1481.

PYTLIŃSKA-SPISS, Anna (1989). Muzea na wolnym powietrzu w Polsce. In: Etnografia Polska, 33 (2), p. 195-220. ISSN 0071-1861.

REYCHMAN, Jan, REYCHMAN, Stefan (1937). Prz̧emyst wiejski na Podhalu. Zakopane: Muzeum Tatrzańskie w Zakopanem.

REYNOLDS, Terry S. (2002). Stronger than a Hundred Men: A History of the Vertical Water Wheel. Johns Hopkins Studies in the History of Technology, Book 7, Baltimore-London: Johns Hopkins University Press. ISBN 978-0801872488.

ROSZAK-KWIATEK, Paweł (2014). Młynarstwo tradycyjne ginący zawód? Sprawozdanie z wyjazdu do Wielkiej Brytanii 20.08.-28.08. 2014 r. In: Rocænik Muæeum Górnoślaski Park Etnograficzny w Chorzowie, 2, p. 240-261. ISSN 2353-2734.

SADKOWSKI, Tadeusz (2018). Katalog tradycyjnego budownictwa w Muzeum - Kaszubskim Parku Etnograficznym we Wdzydzach. Wdzydze Kiszewskie: Muzeum Kaszubski Park Etnograficzny we Wdzydzach Kiszewskich. ISBN 8394550851.

SPISS, Anna (1985). Muzea etnograficzne na wolnym powietrzu w Europie. Warszawa: Ośrodek Dokumentacji Zabytków. ISSN 0860-326X.

SPOZ, Jerzy, JAŚKIEWICZ, Jacek, LEWANDOWSKI, Stanisław, SAKOWICZ, Mieczysław, TIERESZKO, Urszula (1998). Sto lat energetyki wodnej na ziemiach polskich. Warszawa: Towarzystwo Elektrowni Wodnych.

SZAXYGIN, Jerzy (2012). Rejestr i ewidencja zabytków nieruchomych oraz ruchomych w działaniach Narodowego Instytutu Dziedzictwa. In: Ochrona Zabytków, 1-2, p. 117-158. ISSN 0029-8247.

SZULC, Witold (1972). Rozwój młynarstwa na polskich ziemiach zachodnich i północnych w XIX i na początku XX wieku. In: Zeszyty Nankowe Uniwersytetu im. Adama Mickiewicza. Historia, 12, p. 109-155. ISSN 0554-8071.

SZUROWA, Bogumiła (2002). Młyny pływające na Nidzie i Wiśle w XVIII i XIX w Kieleckiem. In: Kielecka Teka Skansenowska, 2, p. 97-130.

SZYMAŃSKI, Adam (1985). Udział placówek muzealnych i skansenowskich w pracach nad młynarstwem wietrznym w Polsce. In: Acta Scansenologica, 3, p. 301-317. ISBN 0208-8053.

ŚWIECH, Jan (2017). Ochrona młynarstwa wiejskiego w polskich muzeach na wolnym powietrzu. Założenia i realizacja. In: PRZYBYŁA-DUMIN, Agnieszka, GRABNY, Barbara, ROSZAK-KWIATEK, Paweł (eds.). Mlynarstwo tradycyjne - wczoraj, dzis, jutro... Problemy zachowania ginacego dziedzictwa. Chorzów: Muzeum „Górnośląski Park Etnograficzny w Chorzowie”. 
p. 141-152. ISBN 978-83-948607-2-1.

WESOLOWSKA, Henryka (1961). Etnograficzne badania nad mtynarstwem wiejskim Opolszrzyzny (wiatraki). Opole: Instytut Śląski w Opolu.

WESOLOWSKA, Henryka (1963). Etnograficzne badania nad mlynarstwem wiejskim Opolszrayzny (mtyny wodne). Opole: Instytut Śląski w Opolu.

WIKANDER, Örjan (1985). Archaeological Evidence for Early Water-Mills - an Interim Report. In: SMITH, Norman (Ed.). History of Technology, 10, p. 151-180. ISBN 9781350018433.

ZIMNA-KAWECKA, Karolina (2010). Ochrona zabytków i organizacja urzędów konserwatorskich w Polsce okresu międzywojennego (na przykładzie woj. pomorskiego) a unormowania Ustawy z dn. 23 VII 2003 r. o ochronie zabytków i opiece nad zabytkami. In: Wiadomości Konserwatorskie, 27, p. 123-144. ISSN 0860-2395.

Legal acts:

Decree of the Regency Council about Care for Monuments of Art and Culture (Journal of Laws 1918, No. 16, item 36).

The Act dated 15 February 1962 on the Protection of Cultural Property and Museums (Journal of Laws 1962, No. 10, item 48).

The Act dated 23 July 2003 on the Protection of Monuments and Care for Monuments (Journal of Laws 2003, No. 162, item 1568, as amended).

Source Materials:

DOMAGA£A, Tadeusz (1970-1971). Wiatraki w wojewódžtwie gdańskim. Vol. 1-5, Historical and conservation documentation at the National Heritage Institute, Branch Gdańsk, signature: $\mathrm{ZN} / 2430$.

\section{Internet pages:}

Website presenting data gathered by Society for Protection of Monuments of the Past, accessed August $4^{\text {th }}, 2020$, http://www.tonzp.dziedzictwowizualne.pl/szukaj?q=wiatrak.

Register of immovable monuments of Kujawsko - Pomorskie voivodeship published on website of National Heritage Institute, accessed August 4th, 2020, https://www.nid.pl/pl/Informacje_ogolne/Zabytki_w_ Polsce/rejestr-zabytkow/zestawienia-zabytkow-nieruchomych/stan\%20na\%2030.06.2019/KUJ-rej.pdf.

Register of immovable monuments of Lubelskie voivodeship published on website of National Heritage Institute, accessed August 4th, 2020, bttps://www.nid.pl/pl/Informacje_ogolne/Zabytki_w_Polsce/ rejestr-zabytkow/zestawienia-zabytkow-nieruchomych/stan\%20na\%2030.06.2019/LBL-rej.pdf.

Register of immovable monuments of the Lubuskie Voivodeship published on the website of the National Heritage Institute, accessed August 4th, 2020, https://www.nid.pl/pl/Informacje_ogolne/Zabytki_w_ Polsce/rejestr-zabytkow/zestawienia-zabytkow-nieruchomych/stan\%20na\%2030.06.2019/LBS-rej.pdf.

Register of immovable monuments of Zachodniopomorskie voivodeship published on website of National Heritage Institute, accessed August 4th, 2020, https://www.nid.pl/pl/Informacje_ogolne/Zabytki_w_ Polsce/rejestr-zabytkow/zestawienia-zabytkow-nieruchomych/stan\%20na\%2030.06.2019/ZPO-rej.pdf.

Website about Hilbert's Mill, accessed accessed August 4 ${ }^{\text {th }}, 2020$, https://www.muzeatechniki. $\mathrm{pl} /$ obiekty/mlyn-hilberta/.

Website about windmills in Poland, accessed August $4^{\text {th }}, 2020$, http:/ /www.wiatraki.org.pl/.

Website of the Milling Musem in Jaracz, accessed August 4 ${ }^{\text {th }}, 2020$, http://www.muzeum-szreniawa.pl/imuzeum/web/app.php/vortal/muzeum_mlynarstwa_w_jaraczu/spotkania_milosnikow_wiatrakow_i_mlynow_wodnych.html. 